\title{
Catalytic characteristics of a copper-alumina nanocomposite formed by the mechanochemical route
}

\author{
Jan Rakoczy • Joanna Nizioł • \\ Krystyna Wieczorek-Ciurowa $\cdot$ Piotr Dulian
}

Received: 5 July 2012/ Accepted: 14 September 2012/Published online: 30 September 2012

(C) The Author(s) 2012. This article is published with open access at Springerlink.com

\begin{abstract}
Mechanochemical synthesis has been successfully employed to prepare $\mathrm{Cu}^{0}-\mathrm{Al}_{2} \mathrm{O}_{3}$ composite powders. The formation of the designed compound is due to the self-propagating reaction of $\mathrm{CuO}$ and $\mathrm{Al}^{\circ}$ powders by high-energy ball milling using a planetary ball mill (Pulverissette 6, Fritsch $\mathrm{GmbH}$ ). The products were characterized by means of nitrogen adsorption (BET surface area), X-ray diffraction, scanning electron microscopy and temperature-programmed reduction of hydrogen. The catalytic properties of the prepared materials were tested in the methanol steam reforming (SRM) process. The results show that the $\mathrm{Cu}^{0}-\mathrm{Al}_{2} \mathrm{O}_{3}$ system is active towards hydrogen in SRM. Hydrogen yields are satisfactory; however, methanol conversion to $\mathrm{CO}$ as a by-product is observed.
\end{abstract}

Keywords $\mathrm{Cu}^{0}-\mathrm{Al}_{2} \mathrm{O}_{3}$ composite catalyst - Methanol steam reforming . SHS mechanochemical reactions · Metal-ceramic nanocomposites

\section{Introduction}

Copper-based catalysts are known due to their high activity and selectivity in processes such as methanol synthesis, water gas shift reaction, selective catalytic reduction of $\mathrm{NO}_{x}$, oxidative methanol steam reforming (SRM) as well as in SRM [1-8]. They are especially important in the last case in spite of the insufficient stability of the process [9-14]. Several possibilities are reported in the literature on the improvement of catalytic properties. Special attention is directed to methods for producing the catalyst considering, among other things, high dispersion on the support and small particle sizes of $\mathrm{Cu}$ and also the addition of promoters [14-19].

J. Rakoczy · J. Nizioł · K. Wieczorek-Ciurowa $(\varangle) \cdot$ P. Dulian

Faculty of Chemical Engineering and Technology, Cracow University of Technology,

24, Warszawska Str., 31-155 Kraków, Poland

e-mail: kwc@pk.edu.pl 
Recently, a detailed review of steam reforming catalysts, also based on copper, was presented by Sá et al. [14].

The conventional methods of syntheses include mainly wet ones, i.e. impregnation and co-precipitation from aqueous solutions or other solvents. These methods are complex, require the use of heat treatment at high temperatures and/or pressures or maintain proper $\mathrm{pH}$ of solution. Moreover, they generate significant amounts of environmentally harmful waste.

Various examples of catalysts can be tested using the above techniques, e.g. the $\mathrm{Cu}(\mathrm{Zn})(\mathrm{Zr})$-alumina prepared through the wet impregnation of metal nitrates as well as co-precipitation using a sodium carbonate and then calcination in both cases (in air at $400{ }^{\circ} \mathrm{C}$ for $4 \mathrm{~h}$ ) $[1,15]$. The co-precipitation method of $\mathrm{Cu} / \mathrm{Zn} / \mathrm{Zr} / \mathrm{Ga}$ oxides applied citric acid solution and then solid residue was thermally treated [20].

Liu et al. [21] had demonstrated not only the conventional, but also a soft reactive milling procedure for copper-manganese spinel synthesis. The precursors of $\mathrm{Cu}$ and Mn were copper hydroxocarbonate and manganese carbonate, respectively, together with solid oxalic acid. The results show the superior performance of mechanochemically synthesized $\mathrm{Cu}-\mathrm{Mn}$ spinel catalyst in the SRM for hydrogen production as compared with the material obtained by co-precipitation.

Taking the environmental problems into account, mechanochemical syntheses are attracting due to their simplicity, freedom of waste and energy efficiency. These syntheses enable the production of new functional materials (including catalysts) with improved and/or novel physical and chemical properties [22-24].

The quality of products strongly depends on the reagents' nature as well as on the mechanochemical treatment conditions. In the $\mathrm{CuO}-\mathrm{Al}$ system, it is possible to synthesize different kinds of composite powders, e.g. $\mathrm{Cu}(\mathrm{Al})-\mathrm{Al}_{2} \mathrm{O}_{3}, \mathrm{Cu}_{9} \mathrm{Al}_{4}-$ $\mathrm{Al}_{2} \mathrm{O}_{3}, \mathrm{CuAl}_{2}-\mathrm{Al}_{2} \mathrm{O}_{3}[25,26]$.

The aim of this study was the formation of well-dispersed $\mathrm{Cu}^{0}$ on $\mathrm{Al}_{2} \mathrm{O}_{3}$ via a self-propagating reaction in the $\mathrm{CuO}-\mathrm{Al}^{0}$ system realized by high-energy ball milling and to show the catalytic characteristics of the copper-alumina composite in the steam reforming of methanol.

\section{Experimental}

Mechanochemical synthesis of the $\mathrm{Cu}^{0}-\mathrm{Al}_{2} \mathrm{O}_{3}$ catalyst and characterization methods

$\mathrm{Cu}^{0}-\mathrm{Al}_{2} \mathrm{O}_{3}$ composite powder was synthesized by the mechanochemical treatment of $\mathrm{CuO}$ (p.a. Fluka) with $\mathrm{Al}^{0}$ (p.a. POCh) powder in 3:2 molar ratio. Milling was carried out in a planetary ball mill (Pulverissette 6, by Fritsch $\mathrm{GmbH}$ ) under $\mathrm{Ar}$ using a vial and balls made of WC. The milling conditions were as follows: $550 \mathrm{rpm}, \mathrm{BPR}=40: 1$, milling time ranged from 0 to $10 \mathrm{~h}$.

X-ray powder diffraction (XRD) patterns were recorded on a Philips X'Pert diffractometer $\left(\mathrm{CuK}_{\alpha}\right)$ in the $2 \theta$ range of $10-90^{\circ}$. A Hitachi S-4700 instrument (scanning electron microscopy [SEM]) equipped with an energy dispersive X-ray spectrometer was used for microstructural examination and elemental microanalysis. 
The BSE imaging and EDX elemental analyses were carried out at an electron beam voltage of $20 \mathrm{kV}$. The specific surface area was estimated by the BET method, and the pore volume and pore size were measured using the BJH method $\left(\mathrm{N}_{2}\right.$ adsorption/ desorption isotherms at $77 \mathrm{~K}$ ) using a Micromeritics ASAP 2020 V3.04 H apparatus, after out-gassing at $250{ }^{\circ} \mathrm{C}$ for $4 \mathrm{~h}$.

Temperature-programmed reduction $\left(\mathrm{H}_{2}-\mathrm{TPR}\right)$ analyses

Temperature-programmed reduction of hydrogen $\left(\mathrm{H}_{2}-\mathrm{TPR}\right)$ is often used to obtain information about metal species with different types of dispersion, and to identify the redox property of a carrier and catalysts system. TPR profiles of coppersupported materials are usually complex, mainly due to particle size of $\mathrm{CuO}$ and its interaction with a carrier.

Reduction was carried out from 50 to $650{ }^{\circ} \mathrm{C}$ with a temperature heating rate of $10{ }^{\circ} \mathrm{C} \mathrm{min}{ }^{-1}$ using a mixture of hydrogen and helium $\left(5 \%\right.$ vol. $\left.\mathrm{H}_{2}\right)$. A thermal conductivity detector (TCD) determined hydrogen consumption. Zeńczak et al. [27] described apparatus used in the present measurements.

Catalytic tests: steam reforming of methanol (SRM)

The catalytic activity of the initial $\mathrm{CuO}-\mathrm{Al}$ mixture and $\mathrm{Cu}^{0}-\mathrm{Al}_{2} \mathrm{O}_{3}$ milling products were studied for comparison. The tests were performed in a pulse microreactor giving an excellent possibility to observe the dynamics of changes in catalyst activity. The microreactor was connected on-line with the chromatograph SRI 8610C equipped with TCD and FID detectors. Porapak Q and 5A molecular sieves columns were used for product separation. Argon as a carrier gas (30 ml min ${ }^{-1}$ ), catalyst in an amount of $0.1 \mathrm{~g}$ (fractions from 0.2 to $0.3 \mathrm{~mm}$ ), and injections $(0.6 \mu \mathrm{l})$ of $\mathrm{CH}_{3} \mathrm{OH}-\mathrm{H}_{2} \mathrm{O}(1: 1)$ pulses up to 40 were used. The reaction temperature was kept $300{ }^{\circ} \mathrm{C}$.

\section{Results and discussion}

Characteristics of materials used in SRM tests

Fig. 1a-c illustrate the XRD patterns of the initial mixture of $\mathrm{CuO}$ with $\mathrm{Al}$ and milling products after 5 and $10 \mathrm{~h}$. After $5 \mathrm{~h}$ as well as $10 \mathrm{~h}$ of milling, the metallic copper and amorphous $\mathrm{Al}_{2} \mathrm{O}_{3}$ were created (according to reaction 1) and some amount of unreacted $\mathrm{CuO}$ and $\mathrm{Al}$ reagents were also present.

$$
3 \mathrm{CuO}+2 \mathrm{Al}^{0} \rightarrow 3 \mathrm{Cu}^{0}+\mathrm{Al}_{2} \mathrm{O}_{3} \quad \Delta H^{\Theta}=-273 \mathrm{~kJ} \mathrm{~mol}^{-1}[28]
$$

SEM images of $\mathrm{CuO}-\mathrm{Al}$ samples are shown in Fig. 2. It can be seen that the textural and crystal size changes as a result of mechanochemical reduction $\mathrm{CuO}$ to $\mathrm{Cu}$. In Fig. 2a, only two phases are present, i.e. initial metallic Al grains partially covered by $\mathrm{CuO}$. After $5 \mathrm{~h}$ of mechanochemical treatment, $\mathrm{Cu}$ species appeared (Fig. 2b, c). 


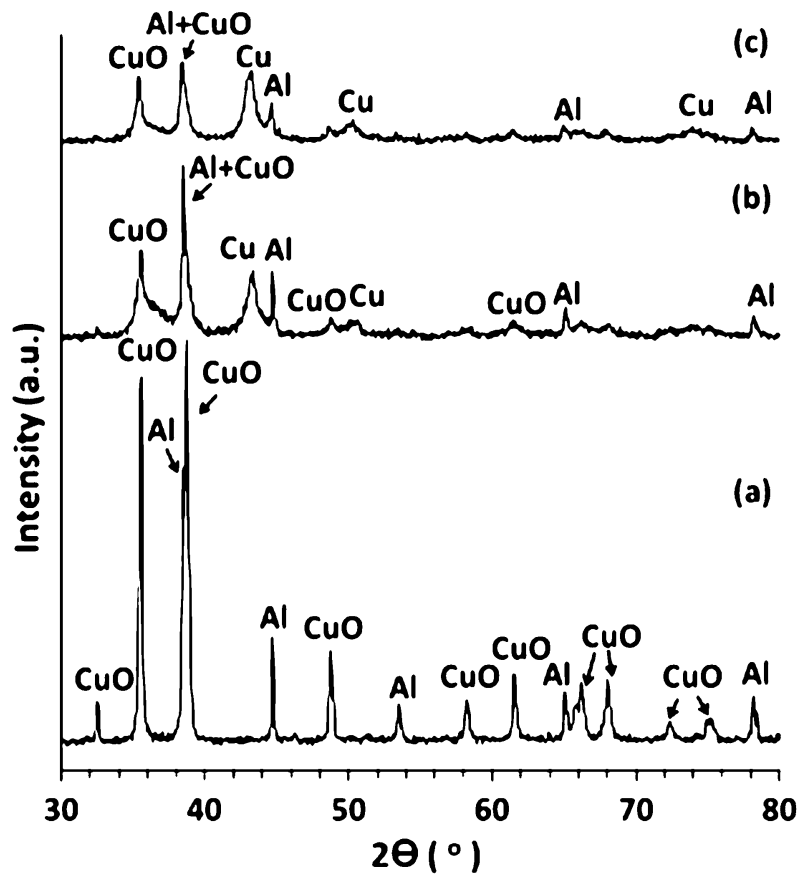

Fig. 1 XRD patterns: $(a) \mathrm{CuO}-\mathrm{Al}$ initial mixture; $(b)$ and $(c)$ products after 5 and $10 \mathrm{~h}$ of milling
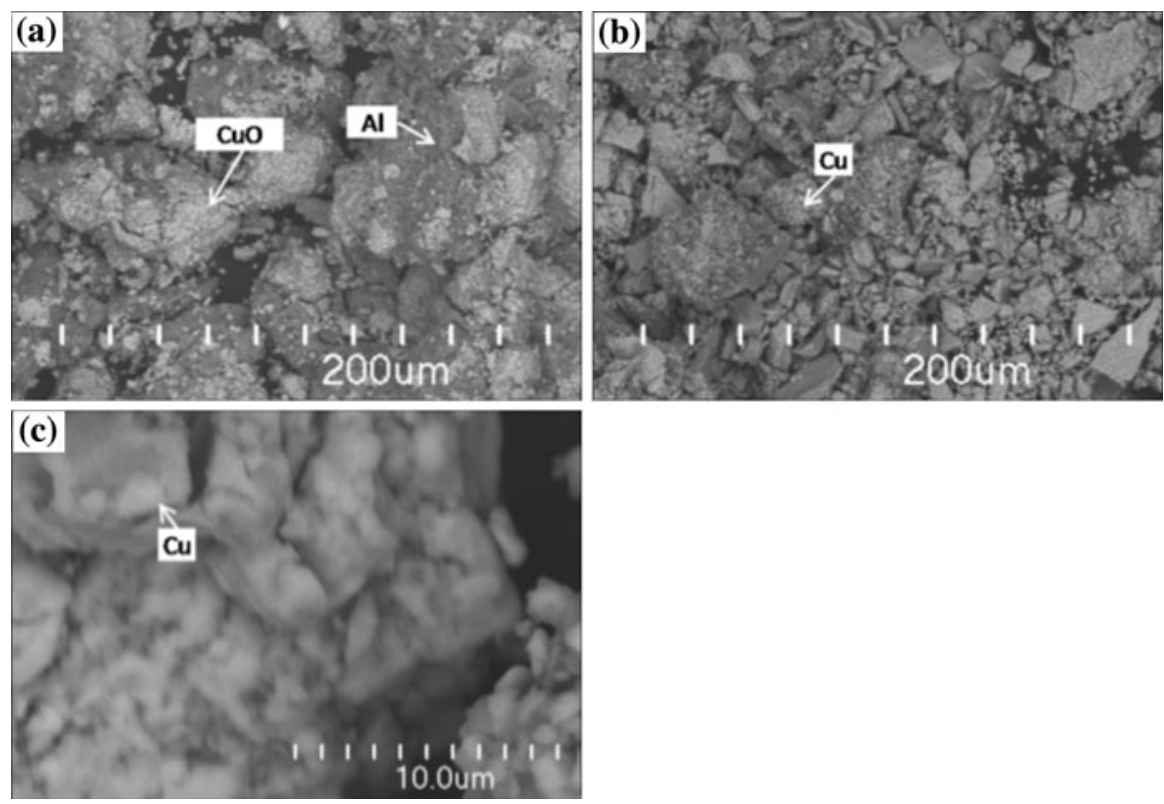

Fig. 2 SEM/BSE images: a CuO-Al initial mixture; b and c products after $5 \mathrm{~h}$ of milling (different magnifications) 
Table 1 Textural properties of the $\mathrm{Cu}-\mathrm{Al}-\mathrm{O}$ system before and after mechanochemical treatment for 5 and $10 \mathrm{~h}$

\begin{tabular}{lllc}
\hline Sample & $\mathrm{S}_{\text {BET }}\left(\mathrm{m}^{2} \mathrm{~g}^{-1}\right)$ & $\mathrm{V}_{\text {BJH }}\left(\mathrm{cm}^{3} \mathrm{~g}^{-1}\right)$ & $\mathrm{S}_{\mathrm{BJH}}(\AA)$ \\
\hline $\mathrm{CuO}-\mathrm{Al} / 0 \mathrm{~h}$ & 1.3 & 0.002 & 318.5 \\
$\mathrm{Cu}-\mathrm{Al}_{2} \mathrm{O}_{3} / 5 \mathrm{~h}$ & 3.9 & 0.009 & 111.9 \\
$\mathrm{Cu}-\mathrm{Al}_{2} \mathrm{O}_{3} / 10 \mathrm{~h}$ & 3.3 & 0.008 & 99.3 \\
\hline
\end{tabular}

Al system are shown in Table 1 . After $5 \mathrm{~h}$ of milling, an increase of surface area was observed. Generally, the BET values are rather low, although the milling process caused threefold increase of surface area. Elongation of milling time (for $10 \mathrm{~h}$ ) involves the agglomeration of powder.

The $\mathrm{H}_{2}$-TPR profiles are shown in Fig. 3. The initial $\mathrm{CuO}-\mathrm{Al}$ mixture shows only one reduction peak with a maximum at $315{ }^{\circ} \mathrm{C}$ (Fig. 3a). This peak can be attributed to the reduction of $\mathrm{CuO}$ (II) to $\mathrm{Cu}^{0}$. Fig. $3 \mathrm{~b}$ shows the reduction of $\mathrm{Cu}^{0}-\mathrm{Al}_{2} \mathrm{O}_{3}-$ $(\mathrm{CuO}+\mathrm{Al})$ system (after $5 \mathrm{~h}$ of milling). Lowering the reduction temperature and decreasing of the hydrogen consumption are evident because of a smaller amount of unreacted $\mathrm{CuO}$ as well as the presence of the activated form of copper oxide. There are two maxima at 183 and $255^{\circ} \mathrm{C}$. This was also observed by Fierro et al. [29].

Phenomena occurring in $\mathrm{Cu}-\mathrm{Al}_{2} \mathrm{O}_{3}$ catalytic system during SRM process

According to reaction 2, the molar composition of main products, $\mathrm{H}_{2}$ and $\mathrm{CO}_{2}$, as well as by-product $\mathrm{CO}$ (reaction 3), were registered as a function of injection numbers of reactant mixture.

$$
\begin{gathered}
\mathrm{CH}_{3} \mathrm{OH}+\mathrm{H}_{2} \mathrm{O} \rightarrow \mathrm{CO}_{2}+3 \mathrm{H}_{2} \quad \Delta H^{\Theta}=49.7 \mathrm{~kJ} \mathrm{~mol}^{-1} \\
\mathrm{CH}_{3} \mathrm{OH} \rightarrow \mathrm{CO}+2 \mathrm{H}_{2} \quad \Delta H^{\Theta}=90.2 \mathrm{~kJ} \mathrm{~mol}^{-1}
\end{gathered}
$$

The total conversion of methanol for all investigated samples is shown in Fig. 4, indicating high values of conversion degrees for milling samples.

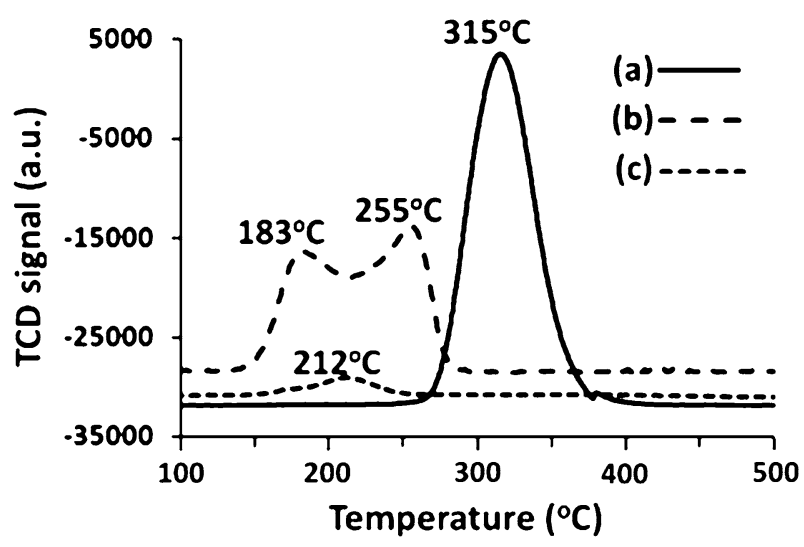

Fig. $3 \mathrm{H}_{2}$-TPR profiles for: (a) $\mathrm{CuO}-\mathrm{Al}$ initial mixture; $(b)$ products after $5 \mathrm{~h}$ milling and $(c)$ products of (b) after SRM at $300{ }^{\circ} \mathrm{C}$ 


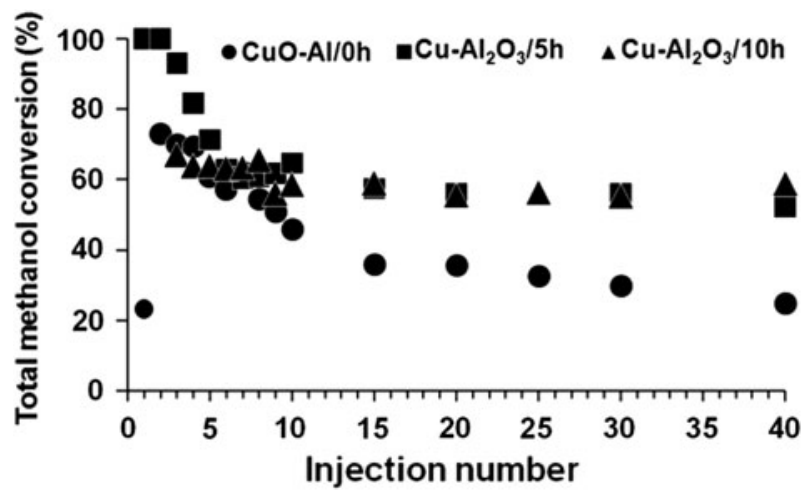

Fig. 4 Total methanol conversion in SRM process at $300{ }^{\circ} \mathrm{C}$ on $\mathrm{Cu}-\mathrm{Al}-\mathrm{O}$ catalyst systems

The course of hydrogen yield is presented in Fig. 5, and molar ratios of $\mathrm{H}_{2} / \mathrm{CO}_{2}$ are collected in Table 2. These values depend on the amount of $\mathrm{CuO}$ in the systems. They are lower than expected one, i.e. stoichiometric value (3.0).

Characteristics of catalysts after SRM reaction

Fig. 6 shows the XRD patterns of $\mathrm{Cu}^{0}-\mathrm{Al}_{2} \mathrm{O}_{3}-(\mathrm{CuO}+\mathrm{Al})$ system after catalytic tests. Higher amounts of metallic copper formed while the reduction of $\mathrm{CuO}$ is evident (compare with Fig. 1a-c). This is confirmed by SEM/BSE images of copper clusters shown in Fig. 7a-c.

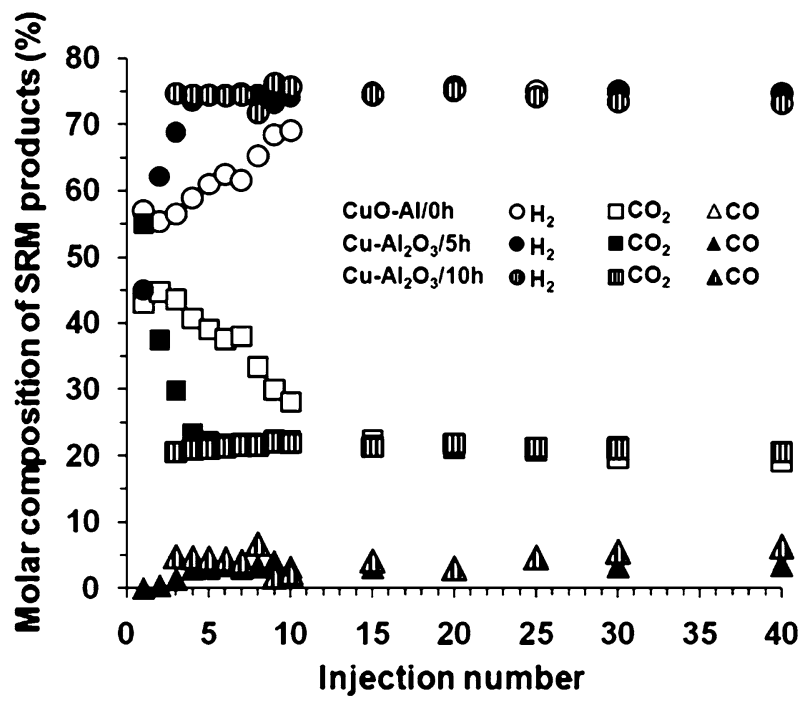

Fig. 5 Molar composition of $\mathrm{H}_{2}, \mathrm{CO}_{2}$ and $\mathrm{CO}$ products of SRM process $\left(300{ }^{\circ} \mathrm{C}\right)$ 
Table 2 Molar ratio of $\mathrm{H}_{2} / \mathrm{CO}_{2}$ in SRM process on $\mathrm{Cu}-\mathrm{Al}-\mathrm{O}$ catalyst systems

\begin{tabular}{llll}
\hline \multirow{2}{*}{$\begin{array}{l}\text { Injection } \\
\text { number }\end{array}$} & \multicolumn{3}{l}{ Molar ratio of $\mathrm{H}_{2} / \mathrm{CO}_{2}$} \\
\cline { 2 - 4 } & $\mathrm{CuO}-\mathrm{Al} / 0 \mathrm{~h}$ & $\mathrm{Cu}-\mathrm{Al}_{2} \mathrm{O}_{3} / 5 \mathrm{~h}$ & $\mathrm{Cu}-\mathrm{Al}_{2} \mathrm{O}_{3} / 10 \mathrm{~h}$ \\
\hline 1 & 1.3 & 1.2 & - \\
2 & 1.2 & 1.7 & - \\
3 & 1.3 & 2.1 & 3.6 \\
4 & 1.4 & 2.5 & 3.6 \\
5 & 1.6 & 2.9 & 3.5 \\
6 & 1.7 & 3.2 & 3.5 \\
7 & 1.6 & 3.3 & 3.5 \\
8 & 2.0 & 3.2 & 3.3 \\
9 & 2.3 & 3.2 & 3.5 \\
10 & 2.5 & 3.3 & 3.5 \\
15 & 3.3 & 3.3 & 3.0 \\
20 & 3.6 & 3.3 & 3.0 \\
30 & 3.8 & 3.3 & 3.0 \\
40 & 3.9 & 3.3 & 3.6 \\
\hline
\end{tabular}

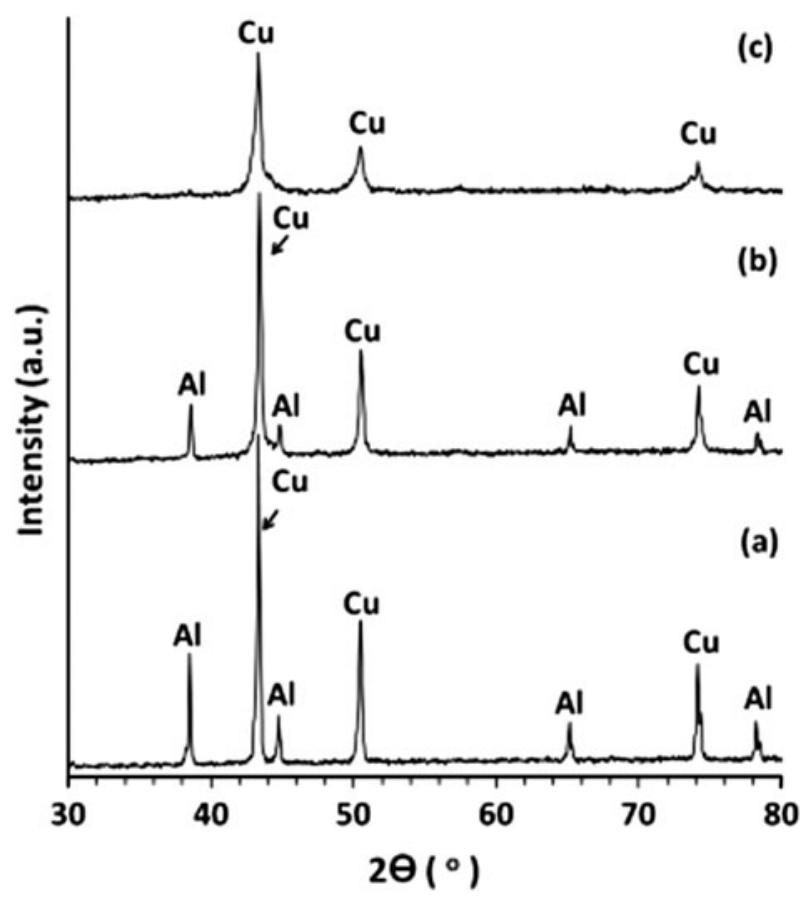

Fig. 6 XRD patterns of SRM process products. Milling time (h) of catalyst from Cu-Al-O system: (a) 0, (b) 5 and (c) 10 

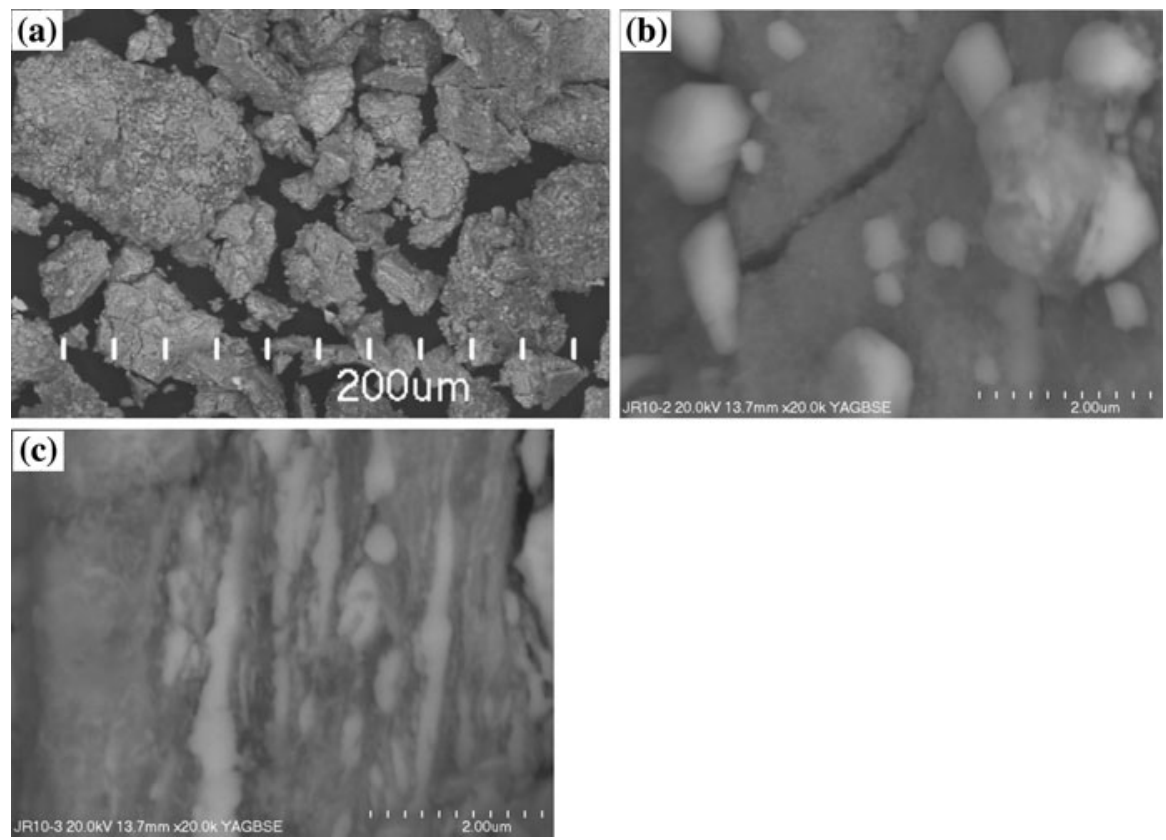

Fig. 7 SEM/BSE images of products after SRM process using sample for $5 \mathrm{~h}$ of milling

$\mathrm{H}_{2}$-TPR measurements were also conducted on the $\mathrm{Cu}-\mathrm{Al}_{2} \mathrm{O}_{3} / 5 \mathrm{~h}$ system after the SRM process. A very low value of $\mathrm{H}_{2}$ consumption indicates the presence of $\mathrm{CuO}$ traces (Fig. 3c).

$$
\mathrm{CuO}+\mathrm{H}_{2} \stackrel{T}{\longrightarrow} \mathrm{Cu}^{0}+\mathrm{H}_{2} \mathrm{O}
$$

\section{Conclusions}

The results showed the possibility of hydrogen production by the steam reforming of methanol using a mechanochemically treated $\mathrm{CuO}-\mathrm{Al}$ system, which creates a copper-based catalyst. The metallic copper formed on $\mathrm{Al}_{2} \mathrm{O}_{3}$ is the active phase in the SRM process. The selectivity towards hydrogen production is satisfactory at $300{ }^{\circ} \mathrm{C}(70 \mathrm{~mol} \%)$, although the methanol reforming to $\mathrm{CO}$ is still present.

Acknowledgments The study is financial supported by the Polish Ministry of Science and Higher Education (Project No. PB N N209 145136) and The European Union through the European Social Fund within "Cracow University of Technology Development Program-top quality teaching for the prospective Polish engineers; University of the 21st century" project (Contract No. UDAPOKL.04.01.01-00-029/10-100). Authors thank to Dr. P. Michorczyk (CUT) for access to the device for measuring $\mathrm{H}_{2}$-TPR.

Open Access This article is distributed under the terms of the Creative Commons Attribution License which permits any use, distribution, and reproduction in any medium, provided the original author(s) and the source are credited. 


\section{References}

1. Matter PH, Ozkan US (2005) J Catal 234:463-475

2. Turco M, Bagnasco G, Costantino U, Marmottini F, Montanari T, Ramis G, Busca G (2004) J Catal 228:43-55

3. Chang F-W, Kuo W-Y, Yang H-C (2005) Appl Catal A 288:53-61

4. Zhang XR, Shi P, Zhao J, Zhao M, Liu C (2003) Fuel Process Technol 83:183-192

5. Pérez-Hernández R, Mondragón Galicia G, Mendoza Anaya D, Palacios J, Angeles-Chavez C, Arenas-Alatorre J (2008) Int J Hydrog Energy 33:4569-4576

6. Kurr P, Kasatkin I, Girgsdies F, Trunschke A, Schlögl R, Ressler T (2008) Appl Catal A 348:153-164

7. Lin K-S, Pan C-Y, Chowdhury S, Lu W, Yeh C-T (2011) Thin Solid Films 519:4681-4686

8. Yang H-M, Chan M-K (2011) Catal Commun 12:1389-1395

9. Purnama H (2003) Steam reforming of methanol. PhD Thesis, TU Berlin (D 83), pp 10, 16-19

10. Mastalir A, Frank B, Szizybalski A, Soerijnto H, Deshpande A, Niederberger M, Schomäcker R, Schlögl R, Ressler T (2005) J Catal 230:464-475

11. Matsumura Y, Ishibe H (2009) Catal J 268:282-289

12. Kameoka S, Okada M, Sai AP (2008) Catal Lett 120:252-256

13. Kuznetsow VV, Vitovsky OV (2008) J Eng Thermophys 17:191-195

14. Sá S, Silva H, Brandão L, Sousa JM, Mendes A (2010) Appl Catal B 99:43-57

15. Patel S, Pant KK (2006) J Porous Mater 13:373-378

16. Wang L, Ding W, Liu Y, Fang W, Yang Y (2010) J Nat Gas Chem 19:487-492

17. Meille V (2006) Appl Catal A 315:1-17

18. Lin K-S, Chowdhury S, Yeh H-P, Hong W-T, Yeh C-T (2011) Catal Today 164:251-256

19. Mrad M, Gennequin C, Aboukaïs A, Abi-Aad E (2011) Catal Today 176:88-92

20. Lachowska M (2010) Reac Kinet Mech Cat 101:85-91

21. Liu Q, Wang L-C, Chen M, Liu Y-M, Cao Y, He H-Y, Fan K-N (2008) Catal Lett 121:144-150

22. Wieczorek-Ciurowa K, Gamrat K (2007) J Therm Anal Calorim 88(1):213-217

23. Wieczorek-Ciurowa K (2010) In: Sopicka-Lizer M (ed) Ch. 9: mechanochemical synthesis of metallic-ceramic composite powders: high-energy ball milling: mechanochemical processing of nanopowders. Woodhead Publishing Ltd., Cambridge

24. Wieczorek-Ciurowa K, Rakoczy J, Błońska-Tabero A, Filipek E, Nizioł J, Dulian P (2011) Catal Today 176:314-317

25. Wieczorek-Ciurowa K, Oleszak D, Gamrat K (2007) Chem Sustain Dev 15:255-258

26. Wieczorek-Ciurowa K, Oleszak D, Gamrat K (2008) Rev Adv Mater Sci 18:248-252

27. Zeńczak K, Michorczyk P, Rachwalik R, Ogonowski J (2010) Czasopismo Techniczne 10-Ch:353-360

28. Schaffer GB, McCormick PG (1990) Metall Trans A 21A:2789-2794

29. Fierro G, Lo Jacono M, Inversi M, Porta P, Lavecchia R, Cioci F (1994) J Catal 148:709-721 